\title{
Assessment of medication adherence and risk factors for hypothyroidism in South Indian Tertiary care hospital: a cross-sectional study
}

\begin{abstract}
The objective of the study was to assess the risk factors for hypothyroidism and the magnitude of medication adherence and the effects of various co-administered drugs on hypothyroidism treatment in a south Indian tertiary care hospital. A cross-sectional study was conducted in 208 subjects (with or without hypothyroidism) from November 2016 to April 2017 in a general medicine department. Odds ratios were calculated in univariate regression analysis for risk factors and magnitude of medication adherence was assessed using MMAS-8 and BMQ questionnaires and the incidence of various prescription drugs interfering with levothyroxine therapy was assessed. Hypothyroidism was significantly higher in the females $(84.6 \%, \mathrm{P}<0.0001)$ with graduation and above level of education (30.8\%, $\mathrm{P}=0.004)$, significant family history $(90.2 \%, \mathrm{P}<0.0001)$, habit of taking fruit juices (monthly once) $(4.9 \%, \mathrm{P}=0.056)$, habit of taking soft drinks (weekly once) $(11.7 \%$, $\mathrm{P}=0.002)$, never work with same efficiency $(24 \%, \mathrm{P}=0.009)$, never with normal sleep pattern (20.4\%, $\mathrm{P}=0.046)$, never take advantage of their free time $(13.5 \%, \mathrm{P}=0.049)$, never likes to be in relationship with others $(14.4 \%, \mathrm{P}=0.001)$ and who never used cardiovascular drugs $(87.5 \%, \mathrm{P}<0.0001)$ than non-hypothyroid subjects. The overall medication adherence level in subjects was found to be $34.6 \%$ according to Morisky-8- item questionnaire and $40.4 \%$ according to BMQ. Levothyroxine $(100 \%)$ was the most widely prescribed drug followed by calcium + vitamin D3 (52.8\%), glimepiride + metformin $(17.28 \%)$, multivitamin + multimineral $(11.52 \%)$ and iron + folic acid $(9.6 \%)$. Among 60 drug-drug interactions identified, $23(38.3 \%)$ were major, $35(58.3 \%)$ were moderate and $2(3.33 \%)$ were minor - drug interactions. The present study suggested that female gender, level of education upto graduation and above, significant family history, habit of taking fruit juices (monthly once), habit of taking soft drinks (weekly once), never work with same efficiency, never with normal sleep pattern, never take advantage of their free time, never likes to be in relationship with others and who never used cardiovascular drugs are at risk for hypothyroidism. Magnitude of medication adherence according to MMAS-8 and BMQ questionnaires was slightly low.
\end{abstract}

Keywords: hypothyroidism, risk factors, medication adherence, mmas- 8 , BMQ and drug interactions
Volume 6 Issue 3 - 2019

Keerthi Annavarapu, ${ }^{1,6}$ Hema Lalitha

Borra,' Rupa Swathi Chakka,' Venkatesh Chennuboina,' Anjani Kumar C, ${ }^{2}$ Naveen Babu Kilaru, ${ }^{3}$ Jaidev Sudhagani, ${ }^{4}$ Ravindrababu Pingili ${ }^{5}$

'Department of Pharmacy Practice, KVSR Siddhartha College of Pharmaceutical Sciences, India

2Department of General Medicine, Dr. Pinnamaneni Siddhartha Institute of Medical Sciences and Research Foundation, India ${ }^{3}$ Department of Pharmaceutics and Pharmaceutical Biotechnology, KVSR Siddhartha College of Pharmaceutical Sciences, India ${ }^{4}$ Endocrinologist, Santhi Nursing Home, India

${ }^{5}$ Department of Pharmacology, KVSR Siddhartha College of Pharmaceutical Sciences, India

${ }^{6}$ Department of Pharmacy Practice, Chalapathi Institute of Pharmaceutical Sciences, India

Correspondence: Ravindrababu Pingili, Department of Pharmacology, KVSR Siddhartha College of Pharmaceutical Sciences, Vijayawada-5200 I0, Andhra Pradesh, India, Tel +91 9885589543, Email ravindrapingili@gmail.com

Received: April 13,2019 | Published: August 16,2019

\section{Introduction}

Thyroid diseases are, arguably, among the commonest endocrine disorders worldwide. India too, is no exception. According to a projection from various studies on thyroid disease, it has been estimated that about 42 million people in India suffer from thyroid diseases. ${ }^{1}$ The prevalence of hypothyroidism in the developed world is about $4-5 \%$. The prevalence of subclinical hypothyroidism in the developed world is about $4-15 \%$. In a developing and densely populated country like India, communicable diseases are priority health concerns due to their large contribution to the national disease burden. ${ }^{2}$ A correct etiological, anatomical and functional diagnosis of the thyroid problem is absolutely essential for the proper treatment and well being of the patient. ${ }^{3}$

For more than four decades, numerous researches on how to properly measure and quantify medication adherence have been conducted but none of them can be counted as the gold standard. Different tools have been designed and validated for different conditions, in different circumstances. Generally, measurements of medication adherence are categorized by the $\mathrm{WHO}$ as subjective and objective measurements. Subjective measurements involve those requiring provider's or patient's evaluation of their medicationtaking behavior. Self-report and healthcare professional assessments are the most common tools used to rate adherence to medication. The most common drawback is that patients tend to underreport nonadherence to avoid disapproval from their healthcare providers. In addition to the classification of adherence measures as subjective and objective, many other studies labeled them as direct and indirect respectively. Direct measures include measurement of the drug or its metabolite concentration in body fluids, such as blood or urine and evaluation of the presence of a biological marker given with the drug and direct observation of patient's medication-taking behavior. An ideal medication adherence measure should present low cost and be user friendly, easy to carry out, highly reliable, flexible, and practical. However, there is no single measure that can meet all these gold standards since each has its own drawbacks. Self-report 
questionnaires, which have a reasonable predictive power, are more useful in a busy, resource-limited clinical setting with moderate to high literacy population. Patient's interview by clinicians is preferred for low literacy population or acts as an adjunct where patients have already been predicted as low medication adherers. Selecting two (or more) medication adherence measures might allow strengths of one method to help compensate putative weakness and to more accurately capture the information needed to determine adherence levels. ${ }^{4}$ Hence we have employed two self - report questionnaires in this study namely, BMQ (Brief Medication Questionnaire) and MMAS-8 (Eight-Item Morisky Medication Adherence Scale) for assessing the medication adherence in hypothyroid patients.

\section{Methodology}

\section{Study design and participants}

It was a prospective study conducted at both in-patients and out-patients department of Dr. Pinnamaneni Siddhartha Institute of Medical Sciences \& Research Foundation, Gannavaram, Andhra Pradesh for a period of 6 months from November 2016 to April 2017. Patients of either sex diagnosed with Hypothyroidism of any duration and some subjects (without Hypothyroidism) were included in the study shown in Figure 1. The protocol for the proposed study was approved by the Institutional Ethics Committee (IEC) of KVSR Siddhartha College of Pharmaceutical Sciences, Vijayawada, Andhra Pradesh.

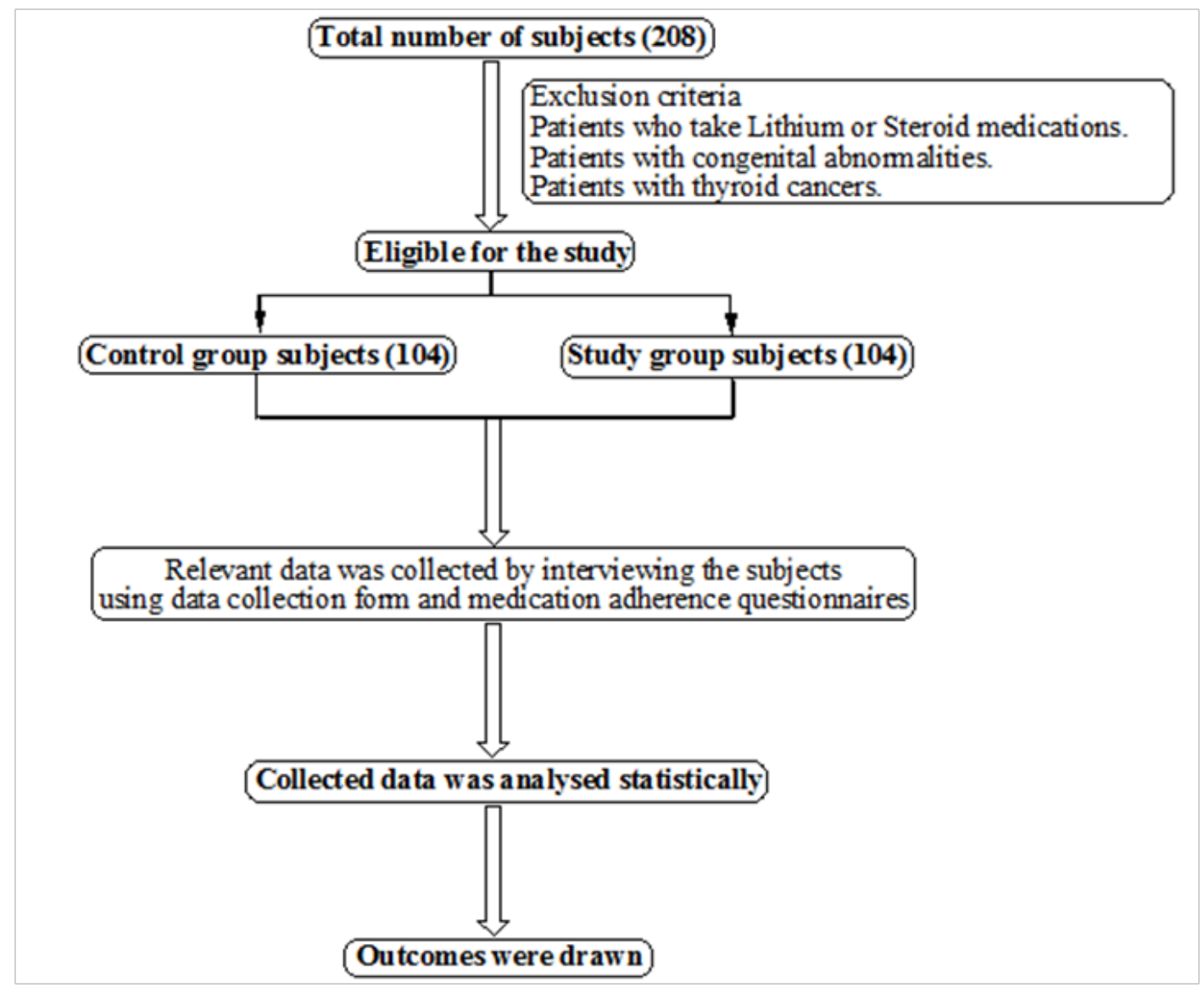

Figure I Study design.

\section{Inclusion criteria}

- Patients with and without Hypothyroidism.

- Patients with age greater than 18 years

- Patients willing to participate in the study

\section{Exclusion criteria}

- Patients who are currently taking Lithium or Steroid medications.

- Patients with congenital abnormalities.
- Patients with thyroid cancers.

\section{Study procedure}

\section{Socio-demographic characteristics and risk factors}

The total patients $(\mathrm{n}=208)$ were divided into Non-Hypothyroid (control, $n=104)$ and Hypothyroid group $(n=104)$. A data collection form for various socio-demographic factors, life style factors, comorbid conditions and clinical characteristics for hypothyroidism was designed. Patient information sheets containing information regarding the study procedure were designed and provided to the study subjects. Consent from the participants who are willing to participate in the study were obtained by employing informed consent forms. 


\section{Assessment of Medication Adherence using MMAS - 8 \& BMQ questionnaires}

Magnitude of medication adherence was assessed by interviewing the subjects using medication adherence questionnaires.

\section{Statistical analysis}

In the descriptive statistical analysis, the categorical variables were expressed as percentages. The univariate analysis was done using chi-square test to determine the strength of association between the variables and hypothyroidism. The risk for the development of hypothyroidism was evaluated by calculating the odds ratio (OR) at
$95 \%$ CI. P-value $<0.05$ was considered significant. Statistical analyses were performed using graph pad prism software (version 7.0).

\section{Results}

A total of 208 patients were included in the study, 104 patients were without hypothyroidism and 104 patients were with hypothyroidism. Socio-demographic characteristics, food and life style characteristics, psychological domain, social and medication domain of patients with and without hypothyroidism were analyzed (Tables 1-4). Univariate regression analysis was performed for modifiable and non-modifiable risk factors of hypothyroidism and results presented in the Table 5.

Table I Socio-demographic characteristics of patients with or without hypothyroidism

\begin{tabular}{|c|c|c|c|}
\hline Variables & Patients without hypothyroidism N (\%) & Patients with hypothyroidism N (\%) & P-value \\
\hline \multicolumn{4}{|l|}{ Gender } \\
\hline Male & $44(42.3)$ & $16(15.4)$ & \\
\hline Female & $60(57.7)$ & $88(84.6)$ & $<0.0001$ \\
\hline \multicolumn{4}{|l|}{ Age } \\
\hline $18-27$ & $7(6.7)$ & $23(22.1)$ & \\
\hline $28-37$ & $5(4.8)$ & $23(22.1)$ & 0.749 \\
\hline $38-47$ & $25(24)$ & $28(26.9)$ & 0.037 \\
\hline $48-57$ & $31(29.8)$ & $16(15.4)$ & 0.0004 \\
\hline $58-67$ & $23(22.1)$ & $10(9.6)$ & 0.0004 \\
\hline$>67$ & $13(12.5)$ & $4(3.8)$ & 0.0006 \\
\hline \multicolumn{4}{|l|}{ Marital status } \\
\hline Unmarried & $7(6.7)$ & $13(12.6)$ & \\
\hline Married & $97(93.3)$ & $90(87.4)$ & 0.166 \\
\hline \multicolumn{4}{|l|}{ Level of education } \\
\hline Illiterate & $37(35.9)$ & $16(15.4)$ & \\
\hline Primary level & $21(20.4)$ & $27(26)$ & 0.0095 \\
\hline Secondary level & $22(21.4)$ & $29(27.9)$ & 0.0097 \\
\hline Graduation and above & $23(22.3)$ & $32(30.8)$ & 0.004 \\
\hline \multicolumn{4}{|l|}{ BMI $\left(\mathrm{Kg} / \mathrm{m}^{2}\right)$} \\
\hline$<25$ & $25(24)$ & $27(26)$ & \\
\hline$>25$ & $79(76)$ & $77(74)$ & 0.873 \\
\hline \multicolumn{4}{|l|}{ Body weight (Kgs) } \\
\hline$<50$ & $9(8.7)$ & $7(6.7)$ & \\
\hline $50-70$ & $35(33.7)$ & $45(43.3)$ & 0.4171 \\
\hline$>70$ & $60(57.7)$ & $52(50)$ & $>0.9999$ \\
\hline \multicolumn{4}{|l|}{ Occupation } \\
\hline Farmer & $9(8.7)$ & $4(3.8)$ & \\
\hline Daily wage worker & $4(3.8)$ & $6(5.8)$ & 0.222 \\
\hline Unemployed & $5(4.8)$ & $5(4.8)$ & 0.417 \\
\hline Government employee & $3(2.9)$ & $3(2.9)$ & 0.617 \\
\hline Private employee & $22(21.2)$ & $14(13.5)$ & 0.743 \\
\hline Retired & $12(11.5)$ & I (I) & 0.322 \\
\hline Housewife & $45(43.3)$ & $64(61.5)$ & 0.076 \\
\hline Student & $4(3.8)$ & $7(6.7)$ & 0.217 \\
\hline
\end{tabular}


Table Continued...

\begin{tabular}{|c|c|c|c|}
\hline Variables & Patients without hypothyroidism N (\%) & Patients with hypothyroidism N (\%) & P-value \\
\hline \multicolumn{4}{|l|}{ Locality } \\
\hline Rural & $51(49)$ & $44(42.3)$ & \\
\hline Urban & $53(5 \mathrm{I})$ & $60(57.7)$ & 0.404 \\
\hline \multicolumn{4}{|l|}{ Monthly income } \\
\hline Sufficient & $44(43.1)$ & $55(53.4)$ & \\
\hline Barely sufficient & $36(35.3)$ & $40(38.8)$ & 0.7602 \\
\hline Not sufficient & $22(21.6)$ & $8(7.8)$ & 0.0067 \\
\hline \multicolumn{4}{|l|}{ Co-morbidities } \\
\hline No co-morbidities & $7(6.7)$ & $60(57.7)$ & \\
\hline Hypertension & $7(6.7)$ & $13(12.5)$ & 0.0151 \\
\hline $\begin{array}{l}\text { Type } 2 \text { Diabetes } \\
\text { Mellitus }\end{array}$ & $68(65.4)$ & $14(13.5)$ & $<0.0001$ \\
\hline $\begin{array}{l}\text { Cerebrovascular } \\
\text { diseases }\end{array}$ & $2(1.9)$ & $2(1.9)$ & 0.076 \\
\hline Pregnancy & $I(I)$ & I (I) & 0.22 \\
\hline Hyperlipidemia & $4(3.8)$ & $3(2.9)$ & 0.008 \\
\hline Heart disease & $10(9.6)$ & $6(5.8)$ & $<0.0001$ \\
\hline \multicolumn{4}{|c|}{ Clinical history of family } \\
\hline Not significant & $74(87.1)$ & $10(9.8)$ & \\
\hline Significant & II (12.9) & $92(90.2)$ & $<0.0001$ \\
\hline
\end{tabular}

BMI, Body mass index

Table 2 Food and life style characteristics of patients with or without hypothyroidism

\begin{tabular}{|c|c|c|c|}
\hline Variables & Patients without hypothyroidism N (\%) & Patients with hypothyroidism N (\%) & P-value \\
\hline \multicolumn{4}{|l|}{ Food habits } \\
\hline Vegetarian & II (I0.6) & $16(15.4)$ & \\
\hline Mixed & $93(89.4)$ & $88(84.6)$ & 0.41 \\
\hline \multicolumn{4}{|l|}{ Physical activity } \\
\hline No & $70(67.3)$ & $58(55.8)$ & \\
\hline Yes & $34(32.7)$ & $46(44.2)$ & 0.117 \\
\hline \multicolumn{4}{|l|}{ Habit of smoking } \\
\hline No & $88(84.6)$ & $99(96.1)$ & \\
\hline Yes & $12(11.5)$ & $3(2.9)$ & 0.016 \\
\hline Past smoker & $4(3.9)$ & $\mathrm{I}(\mathrm{I})$ & 0.196 \\
\hline \multicolumn{4}{|c|}{ Habit of drinking alcohol } \\
\hline No & $93(89.4)$ & $97(94.2)$ & \\
\hline Yes & $8(7.7)$ & $4(3.9)$ & 0.373 \\
\hline Past alcoholic & $3(2.9)$ & $2(1.9)$ & 0.679 \\
\hline \multicolumn{4}{|c|}{ Habit of taking junk foods } \\
\hline No & $66(63.5)$ & $68(65.4)$ & \\
\hline Daily & $4(3.8)$ & $5(4.8)$ & $>0.9999$ \\
\hline Once weekly & $5(4.8)$ & $6(5.8)$ & $>0.9999$ \\
\hline Once in a month & I (I) & $3(2.9)$ & 0.62 \\
\hline Occasionally & $28(26.9)$ & $22(2 \mid .2)$ & 0.508 \\
\hline
\end{tabular}


Table Continued...

\begin{tabular}{|c|c|c|c|}
\hline Variables & Patients without hypothyroidism N (\%) & Patients with hypothyroidism N (\%) & P-value \\
\hline \multicolumn{4}{|c|}{ Habit of taking fruits/fruit juices } \\
\hline No & $16(15.5)$ & $7(6.7)$ & \\
\hline Daily & $32(31.1)$ & $39(37.5)$ & 0.055 \\
\hline Once weekly & $19(18.4)$ & $23(22.1)$ & 0.073 \\
\hline Once in a month & $\mathrm{I}(\mathrm{I})$ & $5(4.9)$ & 0.056 \\
\hline Occasionally & $35(34)$ & $30(28.8)$ & 0.226 \\
\hline \multicolumn{4}{|c|}{ Habit of taking soft drinks } \\
\hline No & $59(56.7)$ & $50(48.5)$ & \\
\hline Once in a week & $I(I)$ & $12(11.7)$ & 0.002 \\
\hline Once in a month & $\mathrm{I}(\mathrm{I})$ & $3(2.9)$ & 0.34 \\
\hline Occasionally & $43(41.3)$ & $38(36.9)$ & $>0.9999$ \\
\hline \multicolumn{4}{|c|}{ Habit of taking tea/coffee } \\
\hline No & $14(13.5)$ & $18(17.3)$ & \\
\hline Occasionally & $6(5.8)$ & $6(5.8)$ & 0.746 \\
\hline Once or twice a day & $62(59.6)$ & $67(64.4)$ & 0.697 \\
\hline Thrice a day and above & $22(21.2)$ & $13(12.5)$ & 0.145 \\
\hline \multicolumn{4}{|c|}{ Situation at working places } \\
\hline No stress & $59(56.7)$ & $55(52.9)$ & \\
\hline Stress & $45(43.3)$ & $49(47.1)$ & 0.676 \\
\hline \multicolumn{4}{|l|}{ Fruits } \\
\hline Daily & $55(55.6)$ & $58(57.4)$ & \\
\hline Weekly & $36(36.4)$ & $31(30.7)$ & 0.54 \\
\hline Monthly & $8(8.1)$ & $12(11.9)$ & 0.628 \\
\hline \multicolumn{4}{|l|}{ Cereals } \\
\hline Daily & $25(25.4)$ & $32(30.8)$ & \\
\hline Weekly & $55(56.1)$ & $6 \mathrm{I}(58.7)$ & 0.746 \\
\hline Monthly & $18(18.4)$ & II (10.6) & 0.17 \\
\hline \multicolumn{4}{|l|}{ Green leafy vegetables } \\
\hline Daily & $36(35.3)$ & $43(41.3)$ & \\
\hline Weekly & 65 (63.7) & $60(57.7)$ & 0.391 \\
\hline Monthly & $\mathrm{I}(\mathrm{I})$ & $\mathrm{I}(\mathrm{I})$ & $>0.9999$ \\
\hline
\end{tabular}

Table 3 Psychological domain of patients with or without hypothyroidism

\begin{tabular}{|c|c|c|c|}
\hline Variables & Patients without hypothyroidism N (\%) & Patients with hypothyroidism N (\%) & P-value \\
\hline \multicolumn{4}{|c|}{ Feels sleep turbulent and disturbance } \\
\hline Always & $15(14.4)$ & $24(23.1)$ & \\
\hline Sometimes & $35(33.7)$ & $23(22.1)$ & 0.04 \\
\hline Never & $54(51.9)$ & $57(54.8)$ & 0.351 \\
\hline \multicolumn{4}{|c|}{ Feels nervous } \\
\hline Always & $5(4.9)$ & $19(18.3)$ & \\
\hline Sometimes & $24(23.3)$ & $36(34.6)$ & 0.129 \\
\hline Never & $74(7 I .8)$ & $49(47.1)$ & 0.0006 \\
\hline
\end{tabular}


Table Continued..

\begin{tabular}{|c|c|c|c|}
\hline Variables & Patients without hypothyroidism N (\%) & Patients with hypothyroidism N (\%) & P-value \\
\hline \multicolumn{4}{|c|}{ Feels disturbing dreams(nightmares) } \\
\hline Always & $8(7.8)$ & $19(18.3)$ & \\
\hline Sometimes & $36(35)$ & $29(27.9)$ & 0.038 \\
\hline Never & $59(57.3)$ & $56(53.8)$ & 0.054 \\
\hline \multicolumn{4}{|c|}{ Feels distress of stomach } \\
\hline Always & $6(5.8)$ & $8(7.8)$ & \\
\hline Sometimes & $32(30.8)$ & $45(43.7)$ & $>0.999$ \\
\hline Never & $66(63.5)$ & $50(48.5)$ & 0.397 \\
\hline \multicolumn{4}{|c|}{ Feels tired quickly } \\
\hline Always & $15(14.6)$ & $29(27.9)$ & \\
\hline Sometimes & $47(45.6)$ & $43(4 \mid .3)$ & 0.065 \\
\hline Never & $4 \mid(39.8)$ & $32(30.8)$ & 0.023 \\
\hline \multicolumn{4}{|c|}{ Feels discomfort while waiting } \\
\hline Always & $14(13.6)$ & $21(20.2)$ & \\
\hline Sometimes & $31(30.1)$ & $40(38.5)$ & 0.835 \\
\hline Never & $58(56.3)$ & $43(4 \mid .3)$ & 0.081 \\
\hline \multicolumn{4}{|c|}{ Concentrate thinking in action } \\
\hline Always & $20(19.2)$ & $27(26)$ & \\
\hline Sometimes & $35(33.7)$ & $35(33.7)$ & 0.455 \\
\hline Never & $49(47.1)$ & $42(40.4)$ & 0.281 \\
\hline \multicolumn{4}{|c|}{ Sweating in cold days } \\
\hline Always & $6(5.8)$ & $16(15.5)$ & \\
\hline Sometimes & $23(22.1)$ & $19(18.4)$ & 0.063 \\
\hline Never & $75(72.1)$ & $68(66)$ & 0.038 \\
\hline \multicolumn{4}{|l|}{ Headache } \\
\hline Always & $6(5.8)$ & $27(26)$ & \\
\hline Sometimes & $63(60.6)$ & $5 \mathrm{I}(49)$ & 0.0002 \\
\hline Never & $35(33.7)$ & $26(25)$ & 0.0004 \\
\hline \multicolumn{4}{|c|}{ Feels anxious for worthless things } \\
\hline Always & $4(3.8)$ & $16(15.5)$ & \\
\hline Sometimes & $37(35.6)$ & 39 (37.9) & 0.024 \\
\hline Never & $63(60.6)$ & $48(46.6)$ & 0.003 \\
\hline \multicolumn{4}{|c|}{ A tense person } \\
\hline Always & $6(5.8)$ & $18(17.3)$ & \\
\hline Sometimes & $52(50)$ & $54(51.9)$ & 0.041 \\
\hline Never & $46(44.2)$ & $32(30.8)$ & 0.005 \\
\hline \multicolumn{4}{|l|}{ Feels sad } \\
\hline Always & $6(5.8)$ & $17(16.3)$ & \\
\hline Sometimes & $51(49)$ & $48(46.2)$ & 0.037 \\
\hline Never & $47(45.2)$ & $39(37.5)$ & 0.019 \\
\hline \multicolumn{4}{|c|}{ Feels pessimistic about the future } \\
\hline Always & $7(6.8)$ & $14(13.6)$ & \\
\hline Sometimes & $28(27.2)$ & $46(44.7)$ & 0.801 \\
\hline Never & $68(66)$ & $43(4 I .7)$ & 0.029 \\
\hline
\end{tabular}


Table Continued..

\begin{tabular}{|c|c|c|c|}
\hline Variables & Patients without hypothyroidism N (\%) & Patients with hypothyroidism N (\%) & P-value \\
\hline \multicolumn{4}{|c|}{ Disappointed in themselves } \\
\hline Always & $6(5.8)$ & $18(17.3)$ & \\
\hline Sometimes & $28(26.9)$ & $4 \mathrm{I}(39.4)$ & 0.222 \\
\hline Never & $70(67.3)$ & $45(43.3)$ & 0.002 \\
\hline \multicolumn{4}{|c|}{ Loss interest in people } \\
\hline Always & $6(5.9)$ & $17(16.3)$ & \\
\hline Sometimes & $20(19.6)$ & $30(28.8)$ & 0.3 \\
\hline Never & $76(74.5)$ & $57(54.8)$ & 0.007 \\
\hline \multicolumn{4}{|c|}{ Works with same efficiency } \\
\hline Always & $73(70.9)$ & $58(55.85)$ & \\
\hline Sometimes & $19(18.4)$ & $21(20.2)$ & 0.372 \\
\hline Never & II (I0.7) & $25(24)$ & 0.009 \\
\hline \multicolumn{4}{|c|}{ Normal sleep pattern } \\
\hline Always & $74(7 \mid .2)$ & $63(6 \mid .2)$ & \\
\hline Sometimes & $20(19.2)$ & $19(18.4)$ & 0.856 \\
\hline Never & $10(9.6)$ & $21(20.4)$ & 0.046 \\
\hline \multicolumn{4}{|c|}{ Tired more quickly than usual } \\
\hline Always & $15(14.4)$ & $30(29.1)$ & \\
\hline Sometimes & $67(64.4)$ & $48(46.6)$ & 0.005 \\
\hline Never & $22(2 \mid .2)$ & $25(24.3)$ & 0.208 \\
\hline \multicolumn{4}{|c|}{ Appetite is not good as before } \\
\hline Always & $4(3.8)$ & $13(12.6)$ & \\
\hline Sometimes & $28(26.9)$ & $33(32)$ & 0.162 \\
\hline Never & $72(69.2)$ & $57(55.3)$ & 0.018 \\
\hline
\end{tabular}

Table 4 Social and medication domain of patients with or without hypothyroidism

\begin{tabular}{|c|c|c|c|}
\hline Variables & Patients without hypothyroidism N (\%) & Patients with hypothyroidism N (\%) & P-value \\
\hline \multicolumn{4}{|c|}{ Do you take advantage of your free time } \\
\hline Always & $44(42.3)$ & $27(26)$ & \\
\hline Sometimes & $52(50)$ & $63(60.6)$ & 0.034 \\
\hline Never & $8(7.7)$ & $14(13.5)$ & 0.049 \\
\hline \multicolumn{4}{|c|}{ Participate in social activities } \\
\hline Always & $12(11.5)$ & $10(9.6)$ & \\
\hline Sometimes & $66(63.5)$ & $54(5 \mid .9)$ & $>0.9999$ \\
\hline Never & $26(25)$ & $40(38.5)$ & 0.227 \\
\hline \multicolumn{4}{|c|}{ Do you like to be relationships with others } \\
\hline Always & $74(71.8)$ & $62(59.6)$ & \\
\hline Sometimes & $27(26.2)$ & $27(26)$ & 0.63 \\
\hline Never & $2(1.9)$ & $15(14.4)$ & 0.001 \\
\hline \multicolumn{4}{|c|}{ Do you deal easily with your colleagues } \\
\hline Always & $64(71.1)$ & $60(58.3)$ & \\
\hline Sometimes & $23(25.6)$ & $32(3 \mid .1)$ & 0.258 \\
\hline Never & $3(3.3)$ & II (I0.7) & 0.047 \\
\hline
\end{tabular}


Table Continued..

\begin{tabular}{|c|c|c|c|}
\hline Variables & Patients without hypothyroidism N (\%) & Patients with hypothyroidism N (\%) & P-value \\
\hline \multicolumn{4}{|c|}{ Are increasing problems during menstrual period } \\
\hline Always & $6(7.1)$ & $14(14.4)$ & \\
\hline Sometimes & $15(17.6)$ & $16(16.5)$ & 0.25 \\
\hline Never & $64(75.3)$ & $67(69.1)$ & 0.15 \\
\hline \multicolumn{4}{|c|}{ Feel anxiety when you stay at home } \\
\hline Always & $2(1.9)$ & $14(13.5)$ & \\
\hline Sometimes & $54(52.4)$ & $53(5 \mathrm{I})$ & 0.006 \\
\hline Never & $47(45.6)$ & $37(35.6)$ & 0.002 \\
\hline \multicolumn{4}{|c|}{ Prefer to stay at home away } \\
\hline Always & $6(5.8)$ & $18(17.3)$ & \\
\hline Sometimes & $62(60.2)$ & $68(65.4)$ & 0.046 \\
\hline Never & $35(34)$ & $18(17.3)$ & 0.001 \\
\hline \multicolumn{4}{|c|}{ Medication domain } \\
\hline \multicolumn{4}{|l|}{ Antacid drugs } \\
\hline Always & $21(20.2)$ & $13(12.6)$ & \\
\hline Sometimes & $31(29.8)$ & $26(25.2)$ & 0.52 \\
\hline Never & $52(50)$ & $64(62.1)$ & 0.118 \\
\hline \multicolumn{4}{|c|}{ Iron and its products } \\
\hline Always & $10(9.6)$ & $8(7.7)$ & \\
\hline Sometimes & $30(28.8)$ & $31(29.8)$ & 0.79 \\
\hline Never & $64(61.5)$ & $65(62.5)$ & 0.802 \\
\hline \multicolumn{4}{|c|}{ Cardiovascular drugs } \\
\hline Always & $4 \mid(39.8)$ & II (I0.6) & \\
\hline Sometimes & $5(4.9)$ & $2(1.9)$ & 0.643 \\
\hline Never & $57(55.3)$ & 91 (87.5) & $<0.0001$ \\
\hline
\end{tabular}

Table 5 Univariate regression analysis of modifiable and non-modifiable risk factors for hypothyroidism

\begin{tabular}{lll}
\hline Variables & OR $(95 \% \mathrm{Cl})$ & P-value \\
\hline Female & $4.033(2.04 \mathrm{I}-7.548)$ & $<0.000 \mathrm{I}$ \\
Marital status & & \\
Unmarried & Ref & \\
Married & $0.500(0.196-1.236)$ & 0.166 \\
Level of education & & \\
Illiterate & Ref & \\
Primary level & $2.973(1.287-6.794)$ & 0.0095 \\
Secondary level & $3.048(1.352-6.8 I I)$ & 0.0097 \\
Graduation and above & $3.217(1.466-7.018)$ & 0.004 \\
BMI (Kg/m2) & & \\
$<25$ & Ref & \\
$>25$ & $0.903(0.48 I-1.677)$ & 0.873 \\
\hline
\end{tabular}


Table Continued.

\begin{tabular}{|c|c|c|}
\hline Variables & OR $(95 \% \mathrm{CI})$ & P-value \\
\hline \multicolumn{3}{|l|}{ Body weight (Kgs) } \\
\hline$<50$ & Ref & \\
\hline $50-70$ & $1.653(0.568-4.466)$ & 0.4171 \\
\hline$>70$ & I.II4 (0.399 - 2.939) & $>0.9999$ \\
\hline \multicolumn{3}{|l|}{ Occupation } \\
\hline Farmer & Ref & \\
\hline Daily wage worker & $3.375(0.544-19.68)$ & 0.222 \\
\hline Unemployed & $2.25(0.433-11.59)$ & 0.417 \\
\hline Government employee & $2.25(0.37 \mid-12.79)$ & 0.617 \\
\hline Private employee & $1.432(0.384-4.809)$ & 0.743 \\
\hline Retired & $0.188(0.014-1.639)$ & 0.322 \\
\hline Housewife & $3.2(0.907-9.776)$ & 0.076 \\
\hline Student & $3.938(0.699-22.04)$ & 0.217 \\
\hline \multicolumn{3}{|l|}{ Locality } \\
\hline Rural & Ref & \\
\hline Urban & $1.312(0.763-2.277)$ & 0.404 \\
\hline \multicolumn{3}{|l|}{ Monthly income } \\
\hline Sufficient & Ref & \\
\hline Barely sufficient & $0.889(0.482-1.64)$ & 0.7602 \\
\hline Not sufficient & $0.291(0.122-0.687)$ & 0.0067 \\
\hline \multicolumn{3}{|l|}{ Co-morbidities } \\
\hline No co-morbidities & Ref & \\
\hline Hypertension & $0.217(0.065-0.7 \mid 4)$ & 0.0151 \\
\hline Type 2Diabetes Mellitus & $0.024(0.010-0.067)$ & $<0.0001$ \\
\hline Cerebrovascular diseases & $0.117(0.017-0.878)$ & 0.076 \\
\hline Pregnancy & $0.117(0.006-2.516)$ & 0.22 \\
\hline Hyperlipidemia & $0.088(0.020-0.401)$ & 0.008 \\
\hline Heart disease & $0.07(0.022-0.278)$ & $<0.0001$ \\
\hline \multicolumn{3}{|l|}{ Clinical history of family } \\
\hline Not significant & Ref & \\
\hline Significant & $61.89(24.55-144.4)$ & $<0.0001$ \\
\hline \multicolumn{3}{|l|}{ Food habits } \\
\hline Vegetarian & Ref & \\
\hline Mixed & $0.651(0.301-1.413)$ & 0.41 \\
\hline \multicolumn{3}{|l|}{ Physical activity } \\
\hline No & Ref & \\
\hline Yes & $1.633(0.922-2.825)$ & 0.117 \\
\hline \multicolumn{3}{|l|}{ Habit of smoking } \\
\hline No & Ref & \\
\hline Yes & $0.222(0.066-0.732)$ & 0.016 \\
\hline Past smoker & $0.222(0.018-1.388)$ & 0.196 \\
\hline
\end{tabular}


Table Continued...

\begin{tabular}{lll}
\hline Variables & OR $(95 \% \mathbf{C I})$ & P-value \\
\hline Habit of drinking alcohol & & \\
No & Ref & 0.373 \\
Yes & $0.479(0.157-1.522)$ & 0.679 \\
Past alcoholic & $0.639(0.112-3.195)$ & \\
Habit of taking junk foods & Ref & \\
No & I.213 $(0.343-4.089)$ & $>0.9999$ \\
Daily & I.I65 $(0.319-3.566)$ & $>0.9999$ \\
Once weekly & $2.912(0.422-38.32)$ & 0.62 \\
Once in a month & $0.763(0.407-1.477)$ & 0.508 \\
Occasionally &
\end{tabular}

Habit of taking fruits/fruit juices

$\begin{array}{lll}\text { No } & \text { Ref } & \\ \text { Daily } & 2.786(1.061-7.045) & 0.055 \\ \text { Once weekly } & 2.767(0.903-7.559) & 0.073 \\ \text { Once in a month } & \text { II.43 (I.465 - 14I.I) } & 0.056 \\ \text { Occasionally } & 1.959(0.730-4.995) & 0.226\end{array}$

Habit of taking soft drinks

No

Once in a week

Once in a month

Occasionally

Habit of taking tea/coffee

No

Occasionally

Once or twice a day

Thrice a day and above

Situation at working places

No stress

\section{Ref}

Stress

I.I $68(0.678-2.021)$

0.676

Green leafy vegetables

\section{Daily}

Weekly

Monthly

\section{Feels slee}

\section{Always}

Sometimes

Never

Feels nervous

\section{Always}

Sometimes

Never

\section{Ref}

$14.16(2.383-154.1) \quad 0.002$

$3.54(0.509-46.65) \quad 0.34$

I.043 (0.592 - I.83I)

$>0.9999$

0.746

0.697

0.145

$\begin{array}{ll}0.84 I(0.397-1.845) & 0.697 \\ 0.460(0.185-1.212) & 0.145\end{array}$

\section{Ref}

$0.773(0.447-1.378) \quad 0.391$

$0.837(0.043-16.31) \quad>0.9999$ 
Table Continued..

\begin{tabular}{lll}
\hline Variables & OR $(95 \%$ CI $)$ & P-value \\
\hline Feels disturbing dreams(nightmares) & \\
Always & Ref & 0.038 \\
Sometimes & $0.339(0.129-0.916)$ & 0.054 \\
Never & $0.400(0.167-0.956)$ & \\
Feels distress of stomach & & \\
Always & Ref & $>0.9999$ \\
Sometimes & I.055 $(0.315-3.122)$ & 0.397 \\
Never & $0.568(0.180-1.845)$ & \\
Feels tired quickly & & 0.065 \\
Always & Ref & 0.023 \\
Sometimes & $0.473(0.229-1.019)$ & \\
Never & $0.404(0.191-0.857)$ & 0.081 \\
Feels discomfort while waiting & \\
Always & Ref & \\
Sometimes & $0.860(0.373-1.88)$ & \\
Never & $0.494(0.231-1.076)$ & \\
\hline
\end{tabular}

Concentrate thinking in action

Always Ref

$\begin{array}{lll}\text { Sometimes } & 0.74 I(0.354-1.5 \mathrm{II}) & 0.455 \\ \text { Never } & 0.635(0.323-1.294) & 0.28 I\end{array}$

Sweating in cold days

Always Ref

Sometimes $\quad 0.310(0.096-0.932) \quad 0.063$

Never $\quad 0.34(0.129-0.938) \quad 0.038$

Headache

Always Ref

$\begin{array}{lll}\text { Sometimes } & 0.180(0.072-0.444) & 0.0002 \\ \text { Never } & 0.165(0.060-0.468) & 0.0004\end{array}$

Feels anxious for worthless things

$\begin{array}{lll}\text { Always } & \text { Ref } & \\ \text { Sometimes } & 0.267(0.090-0.865) & 0.024 \\ \text { Never } & 0.191(0.066-0.587) & 0.003\end{array}$

A tense person

$\begin{array}{lll}\text { Always } & \text { Ref } & \\ \text { Sometimes } & 0.346(0.130-0.955) & 0.041 \\ \text { Never } & 0.232(0.083-0.614) & 0.005 \\ \text { Feels sad } & & \\ \text { Always } & \text { Ref } & \\ \text { Sometimes } & 0.332(0.122-0.870) & 0.037 \\ \text { Never } & 0.293(0.106-0.77) & 0.019\end{array}$

Feels pessimistic about the future

\begin{tabular}{lll} 
Always & Ref & \\
Sometimes & $0.821(0.319-2.275)$ & 0.801 \\
Never & $0.316(0.125-0.810)$ & 0.029 \\
\hline
\end{tabular}

Citation: Annavarapu k, Borra HL, Chakka RS, et al.Assessment of medication adherence and risk factors for hypothyroidism in South Indian Tertiary care hospital: a cross-sectional study.J Diabetes Metab Disord Control. 2019;6(3):60-79. DOI: I0.15406/jdmdc.2019.06.00I84 
Table Continued...

\begin{tabular}{lll}
\hline Variables & OR $(\mathbf{9 5} \% \mathrm{Cl})$ & P-value \\
\hline \multicolumn{2}{l}{ Disappointed in themselves } & \\
Always & Ref & \\
Sometimes & $0.488(0.171-1.333)$ & 0.222 \\
Never & $0.214(0.081-0.588)$ & 0.002 \\
Loss interest in people & & \\
Always & Ref & \\
Sometimes & $0.529(0.172-1.622)$ & 0.3 \\
Never & $0.265(0.100-0.722)$ & 0.007
\end{tabular}

Works with same efficiency

Always Ref

$\begin{array}{lll}\text { Sometimes } & \text { I.39I }(0.672-2.737) & 0.372\end{array}$

$\begin{array}{lll}\text { Never } & 2.86 \mid(1.348-6.109) & 0.009\end{array}$

Normal sleep pattern

$\begin{array}{lll}\text { Always } & \text { Ref } & \\ \text { Sometimes } & 1.116(0.560-2.335) & 0.856 \\ \text { Never } & 2.467(1.082-5.533) & 0.046\end{array}$

Tired more quickly than usual

Always Ref

$\begin{array}{lll}\text { Sometimes } & 0.358(0.17 \mid-0.729) & 0.005\end{array}$

$0.568(0.237-1.286) \quad 0.208$

Appetite is not good as before

$\begin{array}{lll}\text { Always } & \text { Ref } & \\ \text { Sometimes } & 0.363(0.120-1.171) & 0.162 \\ \text { Never } & 0.244(0.084-0.797) & 0.018\end{array}$

Do you take advantage of your free time

$\begin{array}{lll}\text { Always } & \text { Ref } & \\ \text { Sometimes } & 1.974(1.081-3.554) & 0.034 \\ \text { Never } & 2.852(1.073-7.885) & 0.049\end{array}$

Participate in social activities

Always Ref

Sometimes $\quad 0.982(0.409-2.524) \quad>0.9999$

$\begin{array}{lll}\text { Never } & \text { I.846 }(0.684-4.546) & 0.227\end{array}$

Do you like to be relationships with others

$\begin{array}{lll}\text { Always } & \text { Ref } & \\ \text { Sometimes } & \text { I.194 (0.637- 2.24) } & 0.63 \\ \text { Never } & 8.952(2.257-40.26) & 0.001\end{array}$

Do you deal easily with your colleagues

\begin{tabular}{lll} 
Always & Ref & \\
Sometimes & I.484 $(0.789-2.789)$ & 0.258 \\
Never & $0.256(0.074-0.908)$ & 0.047 \\
\hline
\end{tabular}


Table Continued...

\begin{tabular}{lll}
\hline Variables & OR $(95 \% \mathrm{CI})$ & P-value \\
\hline Are increasing problems during menstrual period & \\
Always & Ref & \\
Sometimes & $0.457(0.142-1.523)$ & 0.25 \\
Never & $0.449(0.164-1.182)$ & 0.15
\end{tabular}

Feel anxiety when you stay at home

$\begin{array}{lll}\text { Always } & \text { Ref } & \\ \text { Sometimes } & 0.140(0.031-0.583) & 0.006 \\ \text { Never } & 0.113(0.025-0.486) & 0.002\end{array}$

Prefer to stay at home away

\section{Always}

Sometimes

Never

Antacid drugs

\section{Always}

Sometimes

Never

Iron and its products

\section{Always}

Sometimes

Never

Cardiovascular drugs

\section{Always}

Sometimes

Never

\section{Ref}

$0.366(0.140-0.978)$

$0.17 \mid(0.056-0.510)$

0.046

0.001

\section{Ref}

$0.738(0.327-1.742)$

$1.988(0.92-4.324)$

0.52

0.118

\section{Ref}

I.292 (0.466 - 3.953)

I. 27 (0.488 - 3.446)

0.79

0.802

\section{Ref}

I.49| (0.266 - 9.097)

5.95 I (2.776 - 12.86)
.006
.002

.046

I

\section{Gender}

The incidence of hypothyroidism was higher in females $(84.6 \%)$ compared to males $(15.4 \%)$ and is statistically significant $(\mathrm{P}<0.0001)$. The present study results revealed that there is a significant association between gender and hypothyroidism. Females are at high risk (OR, 4.033; 95\% CI, 2.041 - 7.548; P <0.0001) for hypothyroidism when compared to males.

\section{Age}

The risk of hypothyroidism was higher in age group of $38-47$ (26.9\%) compared to age group of $18-27(22.1 \%)$ and is statistically significant $(\mathrm{P}=0.037)$. The present study results revealed that there was a significant association between age and hypothyroidism.

\section{Marital status}

The incidence of hypothyroidism was higher in married people $(87.4 \%)$ when compared to unmarried people $(12.6 \%)$ but it is statistically not significant $(\mathrm{P}=0.166)$. The present study results revealed that there was a significant association between marital status and hypothyroidism.

\section{Level of education}

With increasing the level of education there was a significant increase in the risk of hypothyroidism. Primary level ( $26 \%, \mathrm{P}=0.0095)$, secondary level $(27.9 \%, \mathrm{P}=0.0097)$, graduation level and above
(30.8\%, $\mathrm{P}=0.004)$ when compared to patients who are uneducated 16 $(15.4 \%)$. The present study results revealed that there was a significant association between level of education and hypothyroidism. People who received graduation and above are at high risk (OR, 3.217; $95 \% \mathrm{CI}, 1.466-7.018 ; \mathrm{P}=0.004)$ than people with secondary level education (OR, 3.048; 95\% CI, $1.352-6.811 ; \mathrm{P}=0.0097)$. The risk was also increased in people with primary level education (OR, $2.973 ; 95 \%$ CI, $1.287-6.794 ; \mathrm{P}=0.0095$ ) for hypothyroidism when compared to uneducated.

\section{BMI}

The incidence of hypothyroidism was higher in people with BMI $>25 \mathrm{Kg} / \mathrm{m}^{2}(74 \%)$ when compared to people with $<25 \mathrm{Kg} / \mathrm{m}^{2}(26 \%)$ but statistically not significant $(\mathrm{P}=0.873)$.

\section{Body weight}

According to the results obtained, with increasing body weight there was an increased incidence of hypothyroidism. People with $>70$ Kgs showed high incidence (50\%) than those of 50-70 Kgs (43.3\%) who in turn showed high incidence when compared to those people $<50 \mathrm{Kgs}(6.7 \%)$. But the results are statistically not significant. The present study result reveals that there is a significant association between body weight and hypothyroidism. People $>70 \mathrm{Kgs}$ are at high risk (OR, 1.653; 95\% CI, $0.568-4.466 ; \mathrm{P}>0.9999)$ than 50-70 Kgs people who in turn are at high risk (OR, 1.653; 95\% CI, 0.568 
- 4.466; $\mathrm{P}=0.4171)$ when compared to people of $<50 \mathrm{Kgs}$ body weight.

\section{TFT}

The incidence of SCH $(\mathrm{TSH}<5.5)$ is higher $(54.3 \%)$ than clinical or overt hypothyroidism $(\mathrm{TSH}>5.5)(45.6 \%)$.

\section{TSH}

Incidence of people with TSH $<5.5$ is $54.3 \%$ and in the range of $5.5-10$ is $30.1 \%$ and those with above 10 were $15.5 \%$.

\section{Total serumT4}

The incidence of people with total serum T4 in the range of $0-4.6$ were $42.9 \%$ and $4.6-12$ were $57.1 \%$ and $>12$ were $0 \%$.

\section{Total serum T3}

The incidence of people with total serum T3 in the range of $0-80$ were $76.7 \%$ and $80-180$ were $23.3 \%$ and $>180$ were $0 \%$.

\section{Occupation}

The incidence of hypothyroidism was found to be higher in housewives $(61.5 \%)$ when compared to farmers $(3.8 \%)$, daily wage workers $(5.8 \%)$, unemployed people $(4.8 \%)$, government employees $(2.9 \%)$, private employees $(13.5 \%)$, retired people $(1 \%)$ and students (6.7\%). But the results are statistically not significant $(\mathrm{P}=0.076)$. The present study results revealed that there is a significant association between occupation and hypothyroidism. Housewives are at increased risk (OR, 3.2; 95\% CI, $0.907-9.776 ; \mathrm{P}=0.076)$ for hypothyroidism when compared to others.

\section{Locality}

The incidence of hypothyroidism was higher in urban people (57.7\%) when compared to people living in rural areas (42.3\%) but it is statistically not significant $(\mathrm{P}=0.404)$. According to the results of this study, there is significant association between living locality and hypothyroidism. People living in urban areas are at high risk (OR, $1.312 ; 95 \% \mathrm{CI}, 0.763-2.277 ; \mathrm{P}=0.404$ ) for hypothyroidism when compared to those living in rural areas.

\section{Monthly income}

According to the results obtained, the incidence of hypothyroidism was found to be higher in people with sufficient monthly income $(53.4 \%)$ than barely sufficient $(38.8 \%)$ and not sufficient $(7.8 \%)$ people. The results obtained are statistically significant $(\mathrm{P}=0.0067)$. The present study results revealed that there is significant association between monthly income and hypothyroidism. People with no sufficient monthly income are not at risk (OR, 0.291; 95\% CI, 0.122 $0.687 ; \mathrm{P}=0.0067$ ) for hypothyroidism when compared to those with sufficient and barely sufficient monthly income.

\section{Co-morbidities}

The incidence of hypothyroidism was found to be higher in people with no co-morbidities (57.7\%) when compared to people with T2DM $(13.5 \%)$, hypertension $(12.5 \%)$, heart disease $(5.8 \%)$, hyperlipidemia $(2.9 \%)$, cerebrovascular diseases $(1.9 \%)$ and pregnants $(1 \%)$ but the results obtained are statistically not significant. The present study revealed that there is no significant association between co-morbid conditions and hypothyroidism. People with no co morbidities are not at risk for hypothyroidism when compared to those having T2DM (OR, 0.024; 95\% CI, $0.010-0.067$; $\mathrm{P}<0.0001)$, hypertension (OR,
$0.217 ; 95 \% \mathrm{CI}, 0.065-0.714 ; \mathrm{P}=0.0151)$, hyperlipidemia $(\mathrm{OR}$, $0.088 ; 95 \% \mathrm{CI}, 0.020-0.401 ; \mathrm{P}=0.008)$, heart disease (OR, 0.07; $95 \%$ CI, $0.022-0.278 ; \mathrm{P}<0.0001)$, cerebrovascular disease $(\mathrm{OR}$, $0.117 ; 95 \% \mathrm{CI}, 0.017-0.878 ; \mathrm{P}=0.076)$ and pregnancy $(\mathrm{OR}, 0.117$; $95 \% \mathrm{CI}, 0.006-2.516 ; \mathrm{P}=0.220$ ).

\section{Clinical history of family}

The incidence of hypothyroidism is higher in people with a significant family history of hypothyroidism $(90.2 \%)$ when compared to those with no significant family history $(9.8 \%)$ and the results obtained are statistically significant $(\mathrm{P}<0.0001)$. The present study reveals that there is significant association between clinical history of family and hypothyroidism. People with significant family history are at high risk (OR, 61.89; 95\% CI, $24.55-144.4$; P < 0.0001) for hypothyroidism when compared to those without significant family history.

\section{Duration of thyroid disease}

The incidence of people with thyroid disease since $<1$ year were $21.2 \%, 1-5$ years were $44.2 \%, 6-10$ years were $22.1 \%, 11-15$ years were $3.8 \%, 16-20$ years were $4.8 \%$ and $>20$ years were $3.8 \%$.

\section{Duration of hypothyroidism treatment}

The incidence of people who take hypothyroidism treatment since $<1$ year were $21.1 \%, 1-5$ years were $43.3 \%, 6-10$ years were $22.1 \%$, $11-15$ years were $3.8 \%, 16-20$ years were $4.8 \%$ and $>20$ years were $3.8 \%$.

\section{Food habits}

The incidence of hypothyroidism is higher in those people who take mixed diet $(84.6 \%)$ when compared to vegetarians $(15.4 \%)$ but the results obtained are not statistically significant $(P=0.410)$. The results revealed that there is significant association between food habits and hypothyroidism. People who take mixed diet are at risk (OR, 0.651; 95\% CI, $0.301-1.413 ; \mathrm{P}=0.410$ ) for hypothyroidism when compared to vegetarians.

\section{Green leafy vegetables}

The incidence of hypothyroidism is higher in those who take green leafy vegetables weekly $(57.7 \%)$ than those who take daily $(41.3 \%)$ and monthly (1\%). But the results obtained are statistically not significant. The results revealed that those who take green leafy vegetables weekly (OR, $0.773 ; 95 \% \mathrm{CI}, 0.447-1.378 ; \mathrm{P}=0.391)$ and monthly (OR, 0.837; 95\% CI, $0.043-16.31$; P > 0.9999) are not at risk for hypothyroidism when compared to those who take daily.

\section{Fruits}

The incidence of hypothyroidism is higher in those who take fruits daily (57.4\%) than those who take weekly (30.7\%) and monthly $(11.9 \%)$. But the results obtained are statistically not significant.

\section{Cereals}

The incidence of hypothyroidism is higher in those who take cereals weekly $(58.7 \%)$ than those who take daily $(30.8 \%)$ and monthly (10.6\%) but results are not statistically significant.

\section{Physical activity}

The incidence of hypothyroidism is higher in those people with no physical activity $(55.8 \%)$ when compared to those with physical activity $(44.2 \%)$ but results are statistically not significant $(\mathrm{P}=0.117)$. 
The results revealed that there is no significant association between physical activity and hypothyroidism. People with physical activity are not at risk $(\mathrm{OR}, 1.633 ; 95 \% \mathrm{CI}, 0.922-2.825 ; \mathrm{P}=0.117)$ for hypothyroidism when compared to those with no physical activity.

\section{Habit of smoking}

The incidence of hypothyroidism is higher in people who does not smoke (96.1\%) when compared to smokers $(2.9 \%)$ and past smokers $(1 \%)$ and is statistically significant. There is significant association between smoking habit and hypothyroidism. People with smoking habit (OR, 0.222; 95\% CI, $0.066-0.732 ; \mathrm{P}=0.016$ ) and who are past smokers (OR, $0.222 ; 95 \% \mathrm{CI}, 0.018-1.388 ; \mathrm{P}=0.196)$ are not at risk for hypothyroidism when compared to non - smokers.

\section{Habit of drinking alcohol}

The incidence of hypothyroidism is higher in people who are non - alcoholic (94.2\%) when compared to alcoholics (3.9\%) and past alcoholics $(1.9 \%)$. The results obtained are statistically not significant. The results revealed that there is significant association between habit of drinking alcohol and hypothyroidism. People who drink alcohol (OR, 0.479; 95\% CI, $0.157-1.522 ; \mathrm{P}=0.373)$ and who are past alcoholics (OR, 0.639; 95\% CI, $0.112-3.195 ; \mathrm{P}=0.679)$ are not at risk for hypothyroidism when compared to non - alcoholics.

\section{Habit of taking junk foods}

Incidence of hypothyroidism is higher in people who don't take junk foods $(65.4 \%)$ when compared to those who take daily $(4.8 \%)$, once weekly $(5.8 \%)$, once in a month $(2.9 \%)$ and occasionally $(21.2 \%)$ but the results are not statistically significant. The results revealed that those who take junk foods once in a month (OR, 2.912; 95\% CI, 0.422 $-3.32 ; \mathrm{P}=0.620)$ and once a day $(\mathrm{OR}, 1.213 ; 95 \% \mathrm{CI}, 0.343-4.089$; $\mathrm{P}>0.999)$ and once weekly (OR, 1.165; 95\% CI, $0.319-3.566$; P $>0.999)$ and occasionally (OR, $0.763 ; 95 \% \mathrm{CI}, 0.407-1.477$; $\mathrm{P}=$ 0.508 ) are not at risk for hypothyroidism when compared to those who do not take junk foods.

\section{Habit of taking soft drinks}

Incidence of hypothyroidism is higher in people who don't take soft drinks (48.5\%) when compared to those who take occasionally $(36.9 \%)$, once a week $(11.7 \%)$ and once a month $(2.9 \%)$. The results obtained are statistically significant. The present study results revealed that those who take soft drinks once a week (OR, 14.16; 95\% CI, $2.383-154.1 ; \mathrm{P}=0.002)$, once a month $(\mathrm{OR}, 3.54 ; 95 \% \mathrm{CI}, 0.509-$ $46.65 ; \mathrm{P}=0.340$ ), occasionally (OR, $1.043 ; 95 \% \mathrm{CI}, 0.592-1.831$; P $>0.999$ ) are not at risk for hypothyroidism when compared to those who do not take soft drinks.

\section{Habit of taking fruits / fruit juices}

The incidence of hypothyroidism is higher in people who take fruits / fruit juices daily $(37.5 \%)$ when compared to those who take occasionally (28.8\%), once weekly (22.1\%), who do not take $(6.7 \%)$, who take once in a month (4.9\%). The results obtained are statistically significant. The results revealed that those who take fruits / fruit juices once in a month (OR, 11.43; 95\% CI, $1.465-141.1 ; \mathrm{P}=0.056)$, daily (OR, 2.786; 95\% CI, 1.061 - 7.045; P = 0.055), once weekly (OR, $2.767 ; 95 \% \mathrm{CI}, 0.903-7.559 ; \mathrm{P}=0.073$ ) and occasionally (OR, 1.959; $95 \% \mathrm{CI}, 0.730-4.995 ; \mathrm{P}=0.226)$ are at high risk for hypothyroidism than those who do not take fruits / fruit juices.

\section{Habit of taking tea / coffee}

The incidence of hypothyroidism is higher in those who take tea / coffee once / twice a day (64.4\%) when compared to those who do not take (17.3\%), who take thrice a day and above (12.5\%) and those who take occasionally (5.8\%) bur the results are statistically not significant. The results showed that those who take tea / coffee once / twice a day (OR, 0.841; 95\% CI, $0.397-1.845 ; \mathrm{P}=0.697)$, who take occasionally (OR, $0.778 ; 95 \% \mathrm{CI}, 0.232-2.657 ; \mathrm{P}=0.746)$ and those who take thrice a day and above (OR, $0.460 ; 95 \%$ CI, $0.185-1.212$; $\mathrm{P}=0.145)$ are at risk for hypothyroidism when compared to those who do not take tea / coffee.

\section{Situation at working places}

The incidence of hypothyroidism is higher in those without stress $(52.9 \%)$ than those with stress $(47.1 \%)$ at working places. But the results obtained are not statistically significant. The results revealed that those who have stressful situations at working places are not at risk (OR, 1.168; 95\% CI, $0.678-2.021 ; \mathrm{P}=0.676)$ for hypothyroidism than those without stressful situations at working places

\section{Feels sleep turbulent and disturbance}

The incidence of hypothyroidism was higher in people who never feels sleep turbulent and disturbance (54.8\%) compared to people who feels sleep turbulent and disturbance always (23.1\%), sometimes $(22.1 \%)$ but statistically not significant. The present study results revealed that there is no significant association between people who never feels sleep turbulent and disturbance with hypothyroidism. When compared to people who feels their sleep turbulent and disturbing always, patients who never feels so $(\mathrm{OR}=0.660 ; 95 \% \mathrm{CI}=$ $0.303-1.426, \mathrm{P}=0.351)$ and sometimes feels so $(\mathrm{OR}=0.411 ; 95 \% \mathrm{CI}$ $=0.174-0.983, \mathrm{P}=0.040)$ are not at risk for hypothyroidism.

\section{Feels nervous}

The incidence of hypothyroidism was higher in patients who never feels nervous $(47.1 \%)$ compared to patients who feels nervous always $(18.3 \%)$ and sometimes $(34.6 \%)$ and statistically significant. The present study results revealed that there is a significant association between patients who never feels nervous and hypothyroidism. When compared to people who feels nervous always, patients who never feels nervous $(\mathrm{OR},=0.174 ; 95 \% \mathrm{CI}=0.068-0.504, \mathrm{P}=0.0006)$ are at risk and sometimes feels nervous $(\mathrm{OR}=0.395 ; 95 \% \mathrm{CI}=0.147-$ 1.193, $\mathrm{P}=0.129$ ) are not at risk for hypothyroidism.

\section{Feels disturbing dreams}

The incidence of hypothyroidism was higher in patients who never feels disturbing dreams (nightmares) (53.8\%) compared to patients who feels disturbing dreams (nightmares) always (18.3\%) and sometimes (27.9\%) and statistically significant. The present study results revealed that there is a significant association between patients who never feels disturbing dreams (nightmares) and hypothyroidism. When compared to people who feels disturbing dreams always, patients who sometimes feels disturbing dreams (OR, $=0.339 ; 95 \%$ $\mathrm{CI}=0.129-0.916, \mathrm{P}=0.038)$ are at risk and those who never feels disturbing dreams $(\mathrm{OR}=0.400 ; 95 \% \mathrm{CI}=0.161-0.956, \mathrm{P}=0.054)$ are not at risk for hypothyroidism.

\section{Feels distress of stomach}

The incidence of hypothyroidism was higher in patients who never feels distress of stomach $(48.5 \%)$ compared to patients who feels distress of stomach always (7.8\%) and sometimes (43.7\%) but statistically not significant $(\mathrm{P}=0.397)$. The present study results revealed that there is no significant association between patients who never feels distress of stomach and hypothyroidism. When compared to people who feels distress of stomach always, patients who never feels distress of stomach $(\mathrm{OR},=0.568 ; 95 \% \mathrm{CI}=0.180-1.845$, 
$\mathrm{P}=0.397)$ and sometimes feels distress of stomach $(\mathrm{OR}=1.055 ; 95 \%$ $\mathrm{CI}=0.315-3.122, \mathrm{P}>0.999)$ are not at risk for hypothyroidism.

\section{Feels tired quickly}

The incidence of hypothyroidism was higher in patients who sometimes feels tired quickly (41.3\%) compared to patients who feels tired quickly always $(27.9 \%)$ and never $(30.8 \%)$ and is statistically significant. The present study results revealed that there is a significant association between patients who never get tired quickly and hypothyroidism. Patients who sometimes feels that they get tired quickly $(\mathrm{OR}=0.473 ; 95 \% \mathrm{CI}=0.229-1.091, \mathrm{P}=0.065)$ and those who never feels tired quickly $(\mathrm{OR}=0.404 ; 95 \% \mathrm{CI}=0.191-0.857, \mathrm{P}=$ 0.023 ) are not at risk when compared to people who always feels that they are tired quickly.

\section{Feels discomfort while waiting}

The incidence of hypothyroidism was higher in patients who never feels discomfort while waiting (41.3\%) compared to patients who feels discomfort while waiting always (20.2\%) and sometimes (38.5\%) but statistically not significant. The present study results revealed that there is no significant association between patients who never feels discomfort while waiting and hypothyroidism. Patients who never feels discomfort while waiting $(\mathrm{OR}=0.494 ; 95 \% \mathrm{CI}=0.231-1.076$, $\mathrm{P}=0.081)$ and sometimes feels discomfort while waiting $(\mathrm{OR}=0.860$; $95 \% \mathrm{CI}=0.373-1.88, \mathrm{P}=0.835)$ are not at risk when compared to people who always feels discomfort while waiting.

\section{Concentrate thinking in action}

The incidence of hypothyroidism was higher in patients who never had concentrate thinking in action (40.4\%) compared to patients who feels concentrate thinking in action always $(26 \%)$ and sometime $(33.7 \%)$ but statistically not significant. The present study results revealed that there is no significant association between patients who never had concentrate thinking in action and hypothyroidism. Patients who never had concentrate thinking in action $(\mathrm{OR}=0.635 ; 95 \% \mathrm{CI}=$ $0.323-1.294, \mathrm{P}=0.281)$ and sometimes had concentrate thinking in action $(\mathrm{OR}=0.741 ; 95 \% \mathrm{CI}=0.354-1.511, \mathrm{P}=0.455)$ are not at risk when compared to people who always had concentrate thinking in action.

\section{Sweating in cold days}

The incidence of hypothyroidism was higher in patients who never have sweating in cold days $(66 \%)$ compared to patients who have sweating in cold days always (15.5\%) and sometimes (18.4\%) and is statistically significant. The present study results revealed that there is a significant association between patients who never have sweating in cold days and hypothyroidism. Patients who never have sweating in cold days $(\mathrm{OR}=0.34 ; 95 \% \mathrm{CI}=0.129-0.938, \mathrm{P}=0.038)$ and those who sometimes have sweating in cold days $(\mathrm{OR}=0.310 ; 95 \% \mathrm{CI}=0.096$ $-0.932, \mathrm{P}=0.063)$ are not at risk when compared to people who always have sweating in cold days.

\section{Headache}

The incidence of hypothyroidism was higher in patients who had headache sometimes (49\%) when compared to patients who had headache always (26\%) and never $(25 \%)$ and is statistically significant. The present study results revealed that there is a significant association between patients who had headache and hypothyroidism. Patients who sometimes had headache $(\mathrm{OR}=0.180,95 \% \mathrm{CI}=0.072$ $0.444, \mathrm{P}=0.0002)$ and those who never had headache $(\mathrm{OR}=0.165$,
$95 \% \mathrm{CI}=0.060-0.468, \mathrm{P}=0.0004)$ are not at risk when compared to people who always had headache.

\section{Feels anxious}

The incidence of hypothyroidism was higher in patients who never feels anxious for worthless things (46.6\%) compared to patients who feels anxious for worthless things always $(15.5 \%)$ and sometimes $(37.9 \%)$ and is statistically significant. The present study results revealed that there is a significant association between patients who never feels anxious for worthless things and hypothyroidism. Patients who never feels anxious for worthless things $(\mathrm{OR}=0.191 ; 95 \% \mathrm{CI}$ $=0.066-0.587, \mathrm{P}=0.003)$ and sometimes feels anxious for worthless things $(\mathrm{OR}=0.267 ; 95 \% \mathrm{CI}=0.090-0.865, \mathrm{P}=0.024)$ are not at risk when compared to people who always feels anxious for worthless things.

\section{Feels tensed}

The incidence of hypothyroidism was higher in patients who feels tensed sometimes $(51.9 \%)$ compared to patients who feels tensed always $(17.3 \%)$, never $(30.8 \%)$ and statistically significant. The present study results revealed that there is a significant association between patients who sometimes feels tensed and hypothyroidism. Patients who sometimes feels tensed ( $\mathrm{OR}=0.346 ; 95 \% \mathrm{CI}=0.130$ $0.955, \mathrm{P}=0.041)$ and those who never feels tensed $(\mathrm{OR}=0.232 ; 95 \%$ $\mathrm{CI}=0.083-0.614, \mathrm{P}=0.005)$ are not at risk when compared to people who always feels tensed.

\section{Feels sad}

The incidence of hypothyroidism was higher in patients who feels sad sometimes $(46.2 \%)$ when compared to patients who feels sad always $(16.3 \%)$, never $(37.5 \%)$ and is statistically significant. The present study results revealed that there is a significant association between patients who sometimes feels sad and hypothyroidism. Patients who sometimes feels sad $(\mathrm{OR}=0.332 ; 95 \% \mathrm{CI}=0.122-0.870$, $\mathrm{P}=0.037)$ and those who never feel sad $(\mathrm{OR}=0.293 ; 95 \% \mathrm{CI}=0.106$ $-0.77, \mathrm{P}=0.019)$ are not at risk when compared to people who always feels sad.

\section{Feels pessimistic about future}

The incidence of hypothyroidism was higher in patients who feels pessimistic about the future sometimes (44.7\%) compared to patients who feels pessimistic about the future always (13.6\%), never (41.7\%) and is statistically significant. The present study results revealed that there is a significant association between patients who sometimes feels pessimistic about the future and hypothyroidism. Patients who sometimes feels pessimistic about the future $(\mathrm{OR}=0.821 ; 95 \% \mathrm{CI}=$ $0.319-2.275, \mathrm{P}=0.801)$ and those who never feel pessimistic about the future $(\mathrm{OR}=0.316 ; 95 \% \mathrm{CI}=0.125-0.810, \mathrm{P}=0.029)$ are not at risk when compared to people who always feels pessimistic about the future.

\section{Disappointed in themselves}

The incidence of hypothyroidism was higher in patients who never feels disappointed in themselves $(43.3 \%)$ when compared to patients who feels disappointed in themselves always (17.3\%) and sometimes $(39.4 \%)$ and is statistically significant. The present study results revealed that there is a significant association between patients who never feels disappointed in themselves and hypothyroidism. Patients who never feels disappointed in themselves $(\mathrm{OR}=0.214 ; 95 \% \mathrm{CI}=$ $0.081-0.588, \mathrm{P}=0.002)$ and those who sometimes feels disappointed 
in themselves $(\mathrm{OR}=0.488 ; 95 \% \mathrm{CI}=0.171-1.333, \mathrm{P}=0.222)$ are not at risk when compared to people who always feels disappointed in themselves.

\section{Lose interest in people}

The incidence of hypothyroidism was higher in patients who never lose interest in people (54.8\%) compared to patients who lose interest in people always $(16.3 \%)$ and sometimes $(28.8 \%)$ and is statistically significant. The present study results revealed that there is a significant association between patients who never lose interest in people with hypothyroidism. Patients who never lose interest in people $(\mathrm{OR}=$ $0.265 ; 95 \% \mathrm{CI}=0.100-0.722, \mathrm{P}=0.007)$ and those who sometimes lose interest in people $(\mathrm{OR}=0.529 ; 95 \% \mathrm{CI}=0.172-1.622, \mathrm{P}=0.300)$ are not at risk when compared to people who always lose interest in people.

\section{Work with same efficiency}

The incidence of hypothyroidism was higher in patients who always feels that they work with same efficiency (55.85\%) when compared to patients who feels that they work with same efficiency never $(24 \%)$ and sometimes $(20.2 \%)$ and is statistically significant The present study results revealed that there is a significant association between patients who feels that they never work with same efficiency and hypothyroidism. When compared to people who works with same efficiency always, patients who never works with same efficiency $(\mathrm{OR}=2.861 ; 95 \% \mathrm{CI}=1.348-6.109, \mathrm{P}=0.009)$ and sometimes works with same efficiency $(\mathrm{OR}=1.391 ; 95 \% \mathrm{CI}=0.672-2.737, \mathrm{P}=0.372)$ are at risk for hypothyroidism.

\section{Normal sleep pattern}

The incidence of hypothyroidism was higher in patients who always had normal sleep pattern $(61.2 \%)$ when compared to patients who never had normal sleep pattern $(20.4 \%)$ and sometimes had normal sleep pattern (18.4\%) and is statistically significant. The present study results revealed that there is a significant association between patients who never had normal sleep pattern and hypothyroidism. Patients who never had normal sleep pattern $(\mathrm{OR}=2.467 ; 95 \% \mathrm{CI}=1.082$ $5.533, \mathrm{P}=0.046)$ and those who sometimes had normal sleep pattern $(\mathrm{OR}=1.116 ; 95 \% \mathrm{CI}=0.560-2.335, \mathrm{P}=0.856)$ are at high risk when compared to people who always had normal sleep pattern.

\section{Feels tired more quickly than usual}

The incidence of hypothyroidism was higher in patients who sometimes feels tired more quickly than usual (46.6\%) when compared to patients who feels tired more quickly always (29.1\%) and never $(24.3 \%)$ and is statistically significant. The present study results revealed that there is a significant association between patients who sometimes feels tired more quickly than usual and hypothyroidism. Patients who never feels tired more quickly than usual $(\mathrm{OR}=0.568$, $95 \% \mathrm{CI}=0.237-1.286, \mathrm{P}=0.208)$ and sometimes feels tired more quickly than usual $(\mathrm{OR}=0.358,95 \% \mathrm{CI}=0.171-0.729, \mathrm{P}=0.005)$ are not at risk when compared to people who always feels tired more quickly than usual.

\section{Appetite is not as good as before}

The incidence of hypothyroidism was higher in patients who never feels that their appetite is not as good as before (55.3\%) when compared to patients who feels that their appetite is not as good as before always (12.6\%) and sometimes (32\%) and is statistically significant. The present study results revealed that there is a significant association between patients who never feels that their appetite not as good as before and hypothyroidism. Patients who never feels their appetite is not as good as before $(\mathrm{OR}=0.244 ; 95 \% \mathrm{CI}=0.084-0.797$, $\mathrm{P}=0.018$ )and sometimes feels that their appetite is not as good as before $(\mathrm{OR}=0.363 ; 95 \% \mathrm{CI}=0.120-1.171, \mathrm{P}=0.162)$ are not at risk when compared to people who always feels that their appetite is not as good as before.

\section{Take advantage of free time}

The incidence of hypothyroidism was higher in patients who sometimes take advantage of free time $(60.6 \%)$ when compared to patients who take advantage of free time always $(26 \%)$ and never $(13.5 \%)$ and is statistically significant. Patients who sometimes take advantage of free time $(\mathrm{OR}=1.974 ; 95 \% \mathrm{CI}=1.081-3.554, \mathrm{P}=0.034)$ and those who never take advantage of their free time $(\mathrm{OR}=2.852$; $95 \% \mathrm{CI}=1.073-7.885, \mathrm{P}=0.049$ ) are at high risk when compared to people who always take advantage of their free time.

\section{Participate in social activities}

The incidence of hypothyroidism was higher in patients who sometimes participate in social activities $(51.9 \%)$ when compared to patients who participate in social activities always (9.6\%) and never $(38.5 \%)$ but statistically not significant. The present study results revealed that there is no significant association between patients who participate in social activities and hypothyroidism. Patients who sometimes participate in social activities are not at risk $(\mathrm{OR}=0.982$; $95 \% \mathrm{CI}=0.409-2.524, \mathrm{P}>0.999)$ and those who never participate in social activities $(\mathrm{OR}=1.846 ; 95 \% \mathrm{CI}=0.684-4.546, \mathrm{P}=0.227)$ when compared to people who always participate in social activities.

\section{Likes to be in relationship with others}

The incidence of hypothyroidism was higher in patients who always likes to be in relationship with others (59.6\%) compared to patients who likes to be in relationship with others never (14.4\%) and sometimes $(26 \%)$ and is statistically significant. The present study results revealed that there is a significant association between patients who never likes to be in relationship with others and hypothyroidism. Patients who never likes to be in relationship with others are at high risk $(\mathrm{OR}=8.952 ; 95 \% \mathrm{CI}=2.257-40.26, \mathrm{P}=0.001)$ and those who sometimes likes to be in relationship with others are at risk $(\mathrm{OR}=$ 1.194; $95 \% \mathrm{CI}=0.637-2.24, \mathrm{P}=0.630$ ) when compared to people who always likes to be in relationship with others.

\section{Deal easily with colleagues}

The incidence of hypothyroidism was higher in patients who always deal easily with colleagues (58.3\%) compared to patients who likes to deal easily with colleagues never $(10.7 \%)$ and sometimes $(31.1 \%)$ and is statistically significant. The present study results revealed that there is a significant association between patients who never deal easily with colleagues and hypothyroidism. Patients who never deal easily with colleagues are not at risk $(\mathrm{OR}=0.256$; $95 \%$ $\mathrm{CI}=0.074-0.908, \mathrm{P}=0.047)$ and who sometimes deal easily with colleagues $(\mathrm{OR}=1.484 ; 95 \% \mathrm{CI}=0.789-2.789, \mathrm{P}=0.258)$ are at risk when compared to people who always deal easily with colleagues.

\section{Increasing problems during menstrual period}

The incidence of hypothyroidism was higher in patients who never have increasing problems during menstrual period $(69.1 \%)$ compared to patients who have increasing problems during menstrual period always (14.4\%) and sometimes (16.5\%) but statistically 
not significant. The present study results revealed that there is no significant association between patients who have increasing problems during menstrual period and hypothyroidism. Patients who never increasing problems during menstrual period $(\mathrm{OR}=0.449,95 \%$ $\mathrm{CI}=0.164-1.182, \mathrm{P}=0.150)$ and those who sometimes have increasing problems during menstrual period $(\mathrm{OR}=0.457,95 \% \mathrm{CI}=0.142$ $-1.523, \mathrm{P}=0.250$ ) are not at risk when compared to people who always have increasing problems during menstrual period.

\section{Anxiety while staying at home}

The incidence of hypothyroidism was higher in patients who sometimes feels anxiety while staying at home (51\%) compared to patients who feels anxiety while staying at home always (13.5\%) and never $(35.6 \%)$ and is statistically significant. The present study results revealed that there is a significant association between patients who sometimes feels anxiety while staying at home and hypothyroidism. Patients who sometimes feels anxiety when staying at home $(\mathrm{OR}=$ $0.140,95 \% \mathrm{CI}=0.031-0.583, \mathrm{P}=0.006)$ and who never feels anxiety while staying at home $(\mathrm{OR}=0.113,95 \% \mathrm{CI}=0.025-0.486, \mathrm{P}=0.002)$ are not at risk when compared to people who always feels anxiety while staying at home.

\section{Prefer to stay at home away}

The incidence of hypothyroidism was higher in patients who sometimes prefer to stay at home away $(65.4 \%)$ compared to patients who prefer to stay at home away always (17.3\%) and never (17.3\%) and is statistically significant. The present study results revealed that there is a significant association between patients who sometimes prefer to stay at home away and hypothyroidism. Patients who sometimes prefer to stay at home away $(\mathrm{OR}=0.366,95 \% \mathrm{CI}=0.140$ $0.976, \mathrm{P}=0.046)$ and those who never prefer to stay at home away $(\mathrm{OR}=0.171,95 \% \mathrm{CI}=0.056-0.510, \mathrm{P}=0.001)$ are not at risk when compared to people who always prefer to stay at home away.

\section{Use of antacids}

The incidence of hypothyroidism was higher in patients never using antacid drugs (62.1\%) when compared to patients using antacid drugs always $(12.6 \%)$ and sometimes $(25.2 \%)$ but statistically not significant. The present study results revealed that there is no significant association between patients using antacid drugs and hypothyroidism. Patients who never use antacids are at risk $(\mathrm{OR}=1.988,95 \% \mathrm{CI}=$ $0.92-4.324, \mathrm{P}=0.118$ ) and who sometimes use antacids are not at risk $(\mathrm{OR}=0.738,95 \% \mathrm{CI}=0.327-1.742, \mathrm{P}=0.520)$ when compared to people who always use antacid drugs.

\section{Use of iron and its products}

The incidence of hypothyroidism was higher in patients who never use iron and its products $(62.5 \%)$ when compared to patients who use iron and its products always (7.7\%) and sometimes (29.8\%) but statistically not significant. The present study results revealed that there is no significant association between patients who use iron and its products and hypothyroidism. Patients who never use iron and its products $(\mathrm{OR}=1.27,95 \% \mathrm{CI}=0.488-3.446, \mathrm{P}=0.802)$ and who sometimes use iron and its products $(\mathrm{OR}=1.292,95 \% \mathrm{CI}=0.466$ $3.953, \mathrm{P}=0.790)$ are at risk when compared to people who always use iron and its products.

\section{Use of cardiovascular drugs}

The incidence of hypothyroidism was higher in patients who never use cardiovascular drugs $(87.5 \%)$ when compared to patients who use cardiovascular drugs always (10.6\%) and sometimes $(1.9 \%)$ and is statistically significant. The present study results revealed that there is a significant association between patients who never use cardiovascular drugs and hypothyroidism. Patients who never use cardiovascular drugs are at high risk $(\mathrm{OR}=5.951,95 \% \mathrm{CI}=2.776$ $12.86, \mathrm{P}<0.0001)$ and those who sometimes take cardiovascular drugs are at risk $(\mathrm{OR}=1.491,95 \% \mathrm{CI}=0.266-9.097, \mathrm{P}=0.643)$ when compared to people who always use cardiovascular drugs.

\section{Medication Adherence}

Medication adherence in hypothyroidism patients was assessed using MMAS -8 and BMQ questionnaires presented in Table 6 . According to MMAS -8 questionnaires, adherence rate was high in $34.6 \%$, moderate in $36.5 \%$ and low in $28.8 \%$ of the subjects. In BMQ questionnaire, 3 screens were employed for assessing medication adherence in hypothyroidism patients. According to regimen screen, adherence rate was $40.4 \%$ and non-adherence rate was $59.6 \%$. As per belief screen adherence rate was $57.3 \%$ and non-adherence rate was $42.7 \%$. In recall screen adherence rate was $43.3 \%$ and non-adherence rate was $56.7 \%$.

Table 6 Medication adherence according to MMAS-8 and BMQ questionnaire

\begin{tabular}{|c|c|}
\hline Variables & Patients with hypothyroidism N (\%) \\
\hline \multicolumn{2}{|c|}{ Medication adherence according to MMAS- 8 item questionnaire } \\
\hline High adherence & $36(34.6)$ \\
\hline Medium adherence & $38(36.5)$ \\
\hline Low adherence & $30(28.8)$ \\
\hline \multicolumn{2}{|c|}{ Medication adherence in regimen screen in BMQ questionnaire } \\
\hline Adherence & $42(40.4)$ \\
\hline Non-adherence & $62(59.6)$ \\
\hline \multicolumn{2}{|c|}{ Medication adherence in belief screen in BMQ questionnaire } \\
\hline Adherence & $59(57.3)$ \\
\hline Non-adherence & $44(42.7)$ \\
\hline \multicolumn{2}{|c|}{ Medication adherence in recall screen in BMQ questionnaire } \\
\hline Adherence & $45(43.3)$ \\
\hline Non-adherence & $59(56.7)$ \\
\hline
\end{tabular}

\section{Drug-Drug Interactions}

A total of 39 moderate drug interactions were observed in study population and presented in the Table 7. The interaction between calcium/vitamin D3 and levothyroxine was identified in $18(46.15 \%)$ prescriptions followed by the interaction between iron and levothyroxine in $8(20.51 \%)$, rabeprazole and levothyroxine in 7 (17.94\%), pantoprazole and levothyroxine in $6(15.38 \%)$. 
Table 7 Moderate drug interactions identified with levothyroxine

\begin{tabular}{|c|c|c|c|c|}
\hline $\begin{array}{l}\text { S. } \\
\text { No }\end{array}$ & $\begin{array}{l}\text { Moderate drug } \\
\text { interaction }\end{array}$ & $\mathbf{N}(\%)$ & Mechanism & Reference \\
\hline I & $\begin{array}{l}\text { Calcium/vitamin D3 + } \\
\text { Levothyroxine }\end{array}$ & $18(46.15)$ & $\begin{array}{l}\text { Calcium salts chelate oral thyroid hormones within the GI tract leads } \\
\text { to decreased thyroid hormone absorption. }\end{array}$ & Singh et al., 200I \\
\hline 2 & Iron + Levothyroxine & $8(20.51)$ & $\begin{array}{l}\text { Iron chelate oral thyroid hormones within the GI tract leads to } \\
\text { decreased thyroid hormone absorption. }\end{array}$ & $\begin{array}{l}\text { Shenandoah et al., } \\
2011\end{array}$ \\
\hline 3 & $\begin{array}{l}\text { Rabeprazole + } \\
\text { Levothyroxine }\end{array}$ & $7(17.94)$ & Increases in TSH levels in patients with hypothyroidism & $\begin{array}{l}\text { Ananthakrishnan } \\
\text { et al., } 2008\end{array}$ \\
\hline 4 & $\begin{array}{l}\text { Pantoprazole }+ \\
\text { Levothyroxine }\end{array}$ & $6(15.38)$ & Increases in TSH levels in patients with hypothyroidism & $\begin{array}{l}\text { Ananthakrishnan } \\
\text { et al., } 2008\end{array}$ \\
\hline
\end{tabular}

\section{Discussion}

Saranya et al. conducted study on Assessment of medication adherence among patients with thyroid dysfunction in a tertiary care centre $-\mathrm{A}$ prospective observational study and interviewed 273 patients who attended the OPD of General Medicine, Govt. Medical College, Thiruvananthapuram using Morisky-8-item and Brief Medication questionnaires for a period of six months. Most of the patients were females (93.8\%) and belongs to the age group of 21-50 years. The overall adherence level was found to be $30 \%$ according to Morisky-8- item questionnaire and $30.4 \%$ according to BMQ. ${ }^{5}$ In the present study female gender $(84.6 \%)$, of age group $38-47$ years $(26.9 \%)$ are more significantly associated with hypothyroidism. The overall adherence level was found to be $34.6 \%$ according to Morisky8 -item questionnaire and $40.4 \%$ according to BMQ.

Perumal et al. conducted a study on Health information seeking behaviour among hypothyroid patients at saveetha medical college and hospital and concluded that majority of participants were females $(71 \%)$ with an average age of 38 years $(S D=12)$ and median age of 39.5 years. ${ }^{6}$ More than half of the participants were married $(71 \%)$. There was not demonstrable difference in locational distribution of the participants (urban $=52 \%$; rural $=48 \%$ ). $23 \%$ were educated up to graduation and above with the highest incidence of hypothyroidism being observed in population educated up to secondary level (40\%) and $38 \%$ of the study population having an annual income between 1,00,001-5,00,000 Indian National Rupee (INR). Majority (44\%) were diagnosed with hypothyroidism in the past $1-5$ years, $35 \%$ of the participants had hypothyroidism from more than 5years and $21 \%$ participants diagnosed to have hypothyroidism within the recent 1 year. In the present study results revealed that majority of participants were females $(84.6 \%)$ within the age group of $38-47$ years $(26.9 \%)$. More than half of the participants were married (87.4\%). There was a demonstrable difference in locational distribution of the participants (urban $=57.7 \%$; rural $=42.3 \%$ ). Majority $44.2 \%$ were diagnosed with hypothyroidism in the past $1-5$ years, $34.5 \%$ of the participants had hypothyroidism from more than 5years and $21.2 \%$ participants diagnosed to have hypothyroidism within the recent 1 year. In the present study the following results are in disagreement with the above study. $30.8 \%$ of study participants were educated upto graduation and above. $38.8 \%$ of study population are having barely sufficient monthly income and highest incidence of hypothyroidism being $53.4 \%$ in sufficient monthly income group. Ngiap et al. conducted a study, primary hypothyroidism in the community: Lower daily dosages of levothyoxine replacement therapy for asian patients and concluded that $79 \%$ of study population were females, $79.5 \%$ were married and $34.9 \%$ were educated up to graduation and above with the highest incidence of hypothyroidism being observed in population educated up to secondary level $(40.2 \%){ }^{7}$ In the present study the majority of participants were females $(84.6 \%)$.More than half of the participants were married (87.4\%). $30.8 \%$ of study participants were educated up to graduation and above.

Ahmed et al. conducted a study on assessment of risk factors related to hypothyroidism for adult patient at Bagdad teaching hospitals and concluded that the majority of the study samples for hypothyroidism (96\%) were females. ${ }^{8} 70 \%$ of the study group occupation is housewife \& $38 \%$ are having barely sufficient monthly income. Regarding residence, majority ( $88 \%$ ) of the study population live in urban setting. The finding of the study group showed that $(56 \%)$ of the patients had family history for hypothyroidism. Finding about psychological domain stated that there was predominance of Major depressive disorder $24.2 \%$, followed by anxiety disorders $(23 \%)$. The p-value of the comparison between the case and the control patients is 0.0001 which is highly significant. The mean of score of social domain for hypothyroidism patients are high on item (Are increasing problems during menstrual cycle days?) and item (Prefer to stay at home away from the eyes of the people).The mean of score is moderate on item (Do take advantage of your free time?), Item (Feel anxiety when you stay at home) and low on the remaining items. The mean of score of medication domain for hypothyroidism patients are high on item (Iron and product), item (Anti-thyroid drugs), item (Cardiovascular drugs) and item (Diuretic drugs).The mean of score is moderate item (Antacids drugs), item (Contraceptive drugs) and item (Sedatives and opiates). In the current study, the majority of the study samples for hypothyroidism (84.6\%) were females. $61.5 \%$ of the study group occupation is housewife \& $38.8 \%$ are having barely sufficient monthly income. Regarding residence, $57.7 \%$ of the study population live in urban setting. The finding of the study group showed that majority $(90.2 \%)$ of the patients had family history for hypothyroidism. In Psychological domain of study group the percentages are high on items (Feels nervous, 52.9\%; Feels distress of stomach, 51.5\%; Feels tired quickly, 69.2\%; Feels discomfort while waiting, 58.7\%; Concentrate thinking in action, 59.7\%; headache, 75\%; Feels anxious for worthless things, 53.4\%; A tense person, $69.2 \%$; Feels sad, $62.5 \%$; Feels pessimistic about the future, 58.3\%; Disappointed in themselves, 56.7\%; Works with same efficiency, $76.05 \%$; Normal sleep pattern, $79.6 \%$; Tired more quickly than usual, $75.7 \%$ )In social domain of study group the percentages are high on items (Take advantage of free time, 86.6\%; Participate in social activities, $61.5 \%$; Like to be in relationship with others, $85.6 \%$; Deal easily with your colleagues, $89.4 \%$; Feel anxiety when you stay at home, $64.5 \%$; Prefer to stay at home away, $82.7 \%$ )

Marjorie et al. conducted a study on co morbidities, concomitant medications, and diet as factors affecting levothyroxine therapy: 
Results of the control surveillance project and concluded that $81.6 \%$ were females and use of dietary supplements $(51.8 \%$, primarily calcium and iron) in the study population. ${ }^{9}$ In the present study, $84.6 \%$ were females and use of calcium + vitamin D3 and iron + folic acid was $62.4 \%$ in the study population. Unnikrishnan et al. conducted a study on Prevalence of hypothyroidism in adults: an epidemiological study in 8 cities in India and concluded that female gender (53.7\%) is significant risk factor for hypothyroidism. ${ }^{2}$ In the current study female gender $(84.6 \%)$ is more significantly associated with Hypothyroidism. Brigitte et al. conducted an observational study of the initial management of hypothyroidism in France: the ORCHIDEE study and concluded that female gender $(84 \%)$ is significant risk factor for hypothyroidism. ${ }^{10}$ In the current study female gender $(84.6 \%)$ is more significantly associated with Hypothyroidism. In the present study a total of 39 moderate drug interactions were observed in study population and presented in the Table 7. Till now, there are no supportive studies discussing the various drug interactions in the prescriptions of hypothyroid patients.

\section{Conclusion}

Hypothyroidism is a most common problem in India and worldwide. The present study results revealed that female gender, level of education up to graduation and above, significant family history, habit of taking fruit juices (monthly once), habit of taking soft drinks (weekly once), never work with same efficiency, never with normal sleep pattern, never take advantage of their free time, never likes to be in relationship with others and who never used cardiovascular drugs are at risk for hypothyroidism. Though therapy is available, the magnitude of medication adherence according to MMAS- 8 and BMQ questionnaires was slightly low because TSH levels are variable in the study population and other co-morbid conditions.

\section{Key findings}

Incidence of hypothyroidism was significantly higher in females compared to males $(\mathrm{P}<0.0001)$.

Hypothyroidism was significantly higher in subjects receiving graduation and above level of education $(\mathrm{P}=0.004)$.

Risk of hypothyroidism was predominantly higher in subjects with a significant family history $(\mathrm{P}<0.0001)$.

Patients with female gender, level of education upto graduation and above, significant family history, habit of taking fruit juices (monthly once), habit of taking soft drinks (weekly once), never work with same efficiency, never with normal sleep pattern, never take advantage of their free time, never likes to be in relationship with others, patients who never used cardiovascular drugs were found to be risk factors for the development of hypothyroidism.

Age, marital status, BMI, body weight, occupation, monthly income, co-morbidities, food habits, physical activity, habit of taking junk foods, habit of taking coffee, habit of taking alcohol, situation at working places were not associated with hypothyroidism.

The overall medication adherence level in subjects was found to be $34.6 \%$ according to Morisky-8- item questionnaire and $40.4 \%$ according to BMQ. Magnitude of medication adherence was slightly low.
The interaction between calcium/vitamin D3 and levothyroxine was identified in $18(18.72 \%)$ prescriptions followed by the interaction between iron and levothyroxine in $8(8.32 \%)$, rabeprazole and levothyroxine in 7 (7.28\%), pantoprazole and levothyroxine in 6 $(6.24 \%)$.

\section{Acknowledgments}

This study was supported by Siddhartha Academy of General and Technical Education (SAGTE). The authors are grateful to N. Venkateswarlu, President and P. Lakshmana Rao, Secretary of SAGTE for providing necessary facilities. The authors thank Dr. G. Devalarao, Pricipal and Dr. Buchi. N. Nalluri, Director for PG studies and Research of KVSR Siddhartha College of Pharmaceutical Sciences, Vijayawada for their encouragement. The authors are grateful to the Physicians of Dr. Pinnamaneni Siddhartha Institute of Medical Sciences and Research Foundation for providing necessary information.

\section{Conflicts of interest}

The authors declare that this research does not have any conflicts of interest with anyone or any institute.

\section{References}

1. Jayakumar RV. Clinical Approach to Thyroid Disease. Supplement to Japi 2011;59:11-13.

2. Ambika GU, Sanjay K, Rakesh KS, et al. Prevalence of hypothyroidism in adults: An epidemiological study in eight cities of India. Indian $J$ Endocrinol Metab. 2013;17(4):647-652.

3. Ambika GU, Usha VM. Thyroid disorders in India: An epidemiological perspective. Indian J Endocrinol Metab. 2011;15(Supply 2): 78-81.

4. Wai YL, Paula F. Medication Adherence Measures: An Overview. BioMed Res Int. 2015;2015:1-12.

5. Saranya D, Jayakrishnan SS, Rajasekharan C. Assessment of medication adherence among patients with thyroid dysfunction in a tertiary care centre - a prospective observational study. World Journal of Pharmaceutical Research. 2016;5(11):1573-1584.

6. Perumal SS, Prasad S, Surapaneni KM, et al. Health Information-Seeking Behavior Among Hypothyroid Patients At Saveetha Medical College And Hospital. Ethiop J Health Sci. 2015; 25(2):147-154.

7. Tan NC, Chew RQ, Koh YL, et al. Primary hypothyroidism in the community Lower daily dosages of levothyroxine replacement therapy for Asian patients. Medicine. 2017;96(7):6145.

8. Ahmed FH, Sabah AA. Assessment of Risk Factors related to Hypothyroidism for Adult Patient at Bagdad Teaching Hospitals. IOSR Journal of Nursing and Health Science. 2016;5(4):28-32.

9. Marjorie MM, Keith SR, Kevin V, et al. Comorbidities, Concomitant Medications, and Diet as Factors Affecting Levothyroxine Therapy: Results of the CONTROL Surveillance Project. Drugs $R \quad D$. 2016;16(1):53-68.

10. Brigitte D, Jean PA, Pierre N, et al. An observational study of the initial management of hypothyroidism in France: the ORCHIDE'E study. Eur $J$ Endocrinol. 2012;167(6):817-823. 